\section{ECONOMICS}

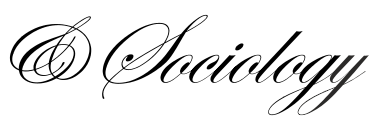

Szalacha-Jarmużek, J., \& Pietrowicz, K. (2018). Missing causality and absent institutionalization. A case of Poland and methodological challenges for future studies of interlocking directorates. Economics and Sociology, 11(4), 157-172. doi:10.14254/2071-789X.2018/11-4/10

\title{
MISSING CAUSALITY AND ABSENT INSTITUTIONALIZATION. A CASE OF POLAND AND \\ METHODOLOGICAL CHALLENGES FOR FUTURE STUDIES OF INTERLOCKING DIRECTORATES
}

\section{Joanna Szalacha-Jarmużek, Institute of Sociology \\ Faculty of Humanities Nicolaus \\ Copernicus University \\ Poland \\ E-mail:joanna.szalacha@umk.pl}

\author{
Krzysztof Pietrowicz, \\ Institute of Sociology \\ Faculty of Humanities, Nicolaus \\ Copernicus University \\ Poland \\ E-mail: \\ kraysztof.pietrowicz@umk.pl
}

Received: May, 2018

1st Revision: August, 2018

Accepted: November, 2018

DOI: $10.14254 / 2071-$

789X.2018/11-4/10

JEL Classification: Z13
ABSTRACT. The paper has two main aims. The first one is to discuss the dominant method applied in the studies on interlocking directorates. We examine the issue raised by a number of scholars, who point out that the studies carried out in the past 50 years have been solely focused on identifying correlations, while little attention has been paid to the causes and consequences of the phenomenon of interlocking directorates. We argue that the dominant method that shapes contemporary studies on interlocks is overly concentrated on quantitative aspects and fails to distinguish between the executive and supervisory boards. Our second aim is to present the ways in which this state of affairs can be remedied. We suggest a mixed-method approach and present the instrumental case study conducted on 122 largest companies operating in Poland. We argue that humanistic coefficient is missing from the studies on interlocking directorates and demonstrate that a different methodological approach might help to fill this void.

Keywords: interlocking directorates, social network analysis, economic sociology, mixed-method approach, Poland.

...most studies focus purely on structural characteristic of the network, which makes more difficult to understand reasons of the changes (Heemskerk \& Schnyder, 2008, p. 41)

\section{Introduction}

The paper has two main aims - the first one is to discuss the dominant method employed in the studies on interlocking directorates and the consequences of exclusive use of such method, i.e. the situation where the majority of the results yielded by such studies are rather unsatisfactory from the perspective of unveiling interests or motivations of 
organizations and individuals. The second aim is to present a possible remedy to this situation in the form of mixed-method approach.

The majority of studies on interlocking directorates share three common features. The research is usually conducted with the exclusive use of social network analysis and the tools that have been developed within its framework over the last 40 years. For this reason, the main focus is on quantitative aspects of interlocks. At the same time, the research is concentrated on organization rather than individuals, with companies placed at the centre of networks. Finally, most studies follow the paths of standards and choices typical of one-tier governance systems. Therefore, the main methodological legacy that shapes interlocks' studies today seems to be characterized by exclusive focus on quantitative aspects and failure to distinguish between executive and supervisory boards.

Furthermore, the research in this area faces two significant problems - the epistemological and methodological one. Firstly, despite the vast amount of research conducted over the last 50 years, it remains unclear whether interlocking directorates are formal or informal in terms of their social character. Which factors have a greater impact on their formation - are they organizational, formal needs or rather, are interlocks an outcome of unregulated, individual mobility of business class members? On a methodological level, the research on interlocking directorates faces an old sociological question of the sources of knowledge and explanations of these social processes that take place at the meeting point of organizational and individual actions, i.e. the problem of methods used to reveal connections between the choices made by social actors and institutional limitations, or an issue of evaluation/measurement the weight or importance of factors that have led to the formation of a given tie (see: Giddens, 1984) .We face the problem of evaluating the causes and factors that underline and support the institution of interlocking directorates, while it seems that full diagnosis of a given institution must encompass the knowledge of its structure and limitations as well as its dynamics (such as the undertaken actions, interests, motivations) and sanctions.

The concentration on quantitative aspects that follows SNA method has led to many studies that lack deeper, sociological meaning and merely present artefacts rather than attempt a social science diagnosis. The mere identification of the shape of networks of interlocking directorates, even if it reveals their qualities such as density, centrality and the like, is insufficient when it comes to providing explanations to a range of significant issues such as a level of institutionalization of interlocking directorates (including positive or negative sanctions, differences in perception of different types of ties and factors, motivations that prevail in creation of ties $\left.{ }^{\mathrm{i}}\right)$. Although these issues are not a direct research problem of this paper, they all lead to one, crucial research question - which method (or methodological approach) is the best to get answers to these sociological problems? Therefore the aim of this paper is to extend knowledge about the dominant method employed in the studies on interlocking directorates and to present a possible remedy to the identified situation.

We must underline here that interlocking directorates are an important phenomenon from the perspective of management issues. Assuming that, as agency theory holds, boards' members are agents of an owner-principal in a company, their every action that takes place outside the firm has an impact on their performance as agents. Closer attention to issues such as motivations to engage in interlocks, factors that lead to the formation of personal ties between companies is obviously crucial for individuals and organizations interested in the success of a large company. Hence, the situation where studies on interlocking directorates fail to provide practical insights while merely presenting a description devoid of practical implications for managers is - let us say this again - a reason for concern.

The paper presents a methodological proposal which will make it more possible to provide answers to the question listed above. We argue that the mixed-method approach can add the much needed meaning and social sensitivity to the studies on interlocking 
directorates. Humanistic coefficient (defined by F. Znaniecki as a need to not limit researchers' observation only to own direct experience of the data and a necessity to reconstruct the experience of the men who are the subject of the research - see: Hałas, 2010) is missing greatly from the studies on interlocking directorates and a different methodological approach might change this state of affairs..

The phenomenon of interlocking directorates is typical of developed capitalism, as the studies conducted for more than 50 years demonstrate generally all large companies have ties with other firms through the board members holding multiply positions (see: Fennema, 1982; Carroll, 2010; Maclean et al., 2006; Ong et al., 2003; Rommens et al., 2007; Useem, 1984; Santos et al., 2012; Scott, 1991). Many researchers have also demonstrated that interlocks play a particular importance in capital markets of certain countries as well as in global economy. Interlocking directorates are perceived through the lens of their relationship with elite-building process (Burris, 2005; Kadushin, 1995; Maclean et al., 2006). They are seen not only as means of boosting efficiency of a company (Mintz \& Schwartz, 1981; Schoorman et al., 1981), but also a source of collusion in business and politics (Buch-Hansen, 2014; Carretta et al., 2012). Other studies also provide examples of connections between interlocks and the development of economic and political strength of a given country (van der Pijl et al., 2011). Taking all these research into account, interlocking directorates are seen as an economic phenomenon shaped by different kinds of rationality of social actors and a range of "rules of games". Our analysis will follow these theoretical paths as well as an actor-oriented approach, which helps to better understand certain changes observed within networks (Heemsker \& Schnyder, 2008).

We will also refer to the research that has been for the first time conducted in Poland, concerning 122 biggest companies in a period 2012-2014. This study has helped us to evaluate the weaknesses of the prevalent methodological approach and draw a blueprint for future studies. Selected results presented in this paper are more an "instrumental case study" (see: Stake, 1994), as the paper refers to the empirical findings to present methodological solutions which were not directly employed in the above research, however, in the authors' opinion should be applied in future studies.

\section{Interlocking directorates studies: State of the art}

Interlocking directorates have been a subject of research carried systematically by social sciences since 1960s. The studies have been conducted in numerous countries with various economic systems, such as the USA, France, Singapore, Chile, the UK, Ireland, Germany, Netherlands, to name but a few (see: Di Donato and Tiscini, 2009; Heemskerk and Schnyder, 2008; Fich and White, 2005; Stening and Wan, 1984; Van Ees and Postma, 2004; Sicilia et al. 2016; Hashim and Rahman 2011; van Veen and Kratzer 2011; Riberio et al. 2016; Pombo and Gutierez, 2011). The problem of the scale of the studied phenomenon was a natural starting point for many researchers who were interested in the number and basic form of connections between companies.

However, the dissatisfaction with the quality of research reaches back as far as 40 years with the researchers pointing to unsatisfactory results of their work. To give one example, D. Bunting and J. Barbour (1971) focused their attention on the number of positions held by directors of the 200 largest American companies in the period between 1896 and 1964. They concentrated mainly on an average number of interlocks and the number of interlocks per company. As successful as their research was in terms of quantitative description of the interlocks, it stumbled upon the problem shared by all quantitative studies, i.e. it failed to provide the explanation of the factors underlying the identified changes. It must be stressed at this point that the majority of methods applied in the research on interlocks and 
their dynamics are rather correlational and they do not focus more on causal aspects (Peng et al., 2000). And as Bunting and Barbour noticed:

We cannot isolate the cause with the information now available (1971, p.329).

The authors were able to identify prominent interlockers (people holding four or more positions), but they were unable to identify and explain the factors underlying this phenomenon. In other words, from the very beginning their research yielded the results that on a certain level were unsatisfactory. Although on a quantitative level these studies presented novel and significant findings, they lacked satisfactory explanations in terms of causality ${ }^{\mathrm{ii}}$. As M. Mizruchi commented:

Schwartz and his students had showed that there were a lot of interlocks, and I had showed that there were a lot of them in the old days and a lot of them in the present. One question began to be raised against this work, however: There may be a lot of interlocks, but so what? What difference does it make? To what extent do these ties affect actual behavior among firms? To what extent do they demonstrate the existence of a capitalist class that acts collectively in a unified manner? (citation from Fennema and Heemskerk, 2016, p.13)

These are the fundamental questions concerning the very existence and scale of interlocking directorates' phenomenon. The main method employed in research was social network analysis (SNA) accompanied by digital tools. As M. Fennema and E. Heemskerk noticed:

[...] mathematical graph theory provided a toolbox for systematic network analysis and that simultaneously in the Netherlands and the United States this toolbox found an application in the study of corporate power (Fennema and Heemskerk, 2016, p.1).

Since the late 1970s the academics studying interlocking directorates have been using computer software to analyze information gathered from official records (the first program used for this purpose was GRADAP, followed by SONET, NEGOPY and STRUCTURE, and since 1983 UCINET which is still in use). These programs helped to discover networks created by those with multiply positions and made it possible to present the outcomes using visual tools such as graphs, etc. Fennema and Heemskerk demonstrate that the concept of networks was supported by general structural approach to social problems, which shifted the research interest from groups of individuals towards organizations (interlocks were presented from the point of view of an organization).

Because the SNA has served as a basic theoretical and methodological tool for studies on interlocking directorates, researchers have sought to describe the qualities of the identified networks in terms of density, centrality, the mean number of ties per person or per company, etc. ${ }^{\text {iii }}$ As is a common case with SNA research, the structure of a network is more important than the quality of nodes creating this network (see: Degenne and Forse, 1999, pp.1-12). Even though the analysis of a network structure renders information about the nodes within the network, it has never been the aim of the SNA to examine the nodes in detail, which renders it blind to specific aspects of interlocks. However certain studies included extra analysis of a range of demographic features of those involved in interlocks such as their nationality, age, or sex (see: Peng et al., 2000), they failed to probe deeper into them and did not proceed further, towards institutional analysis.

On a more general level, the research on interlocking directorates faces methodological problem rooted in the differences between SNA and the neoclassical economy as well as in the division between methodological individualism and holism in economics (Parker, 2006). SNA is based on a structural approach, while economics has always had a strong individualistic angle (in methodological terms in the concept of homo oeconomicus, theory of agency, a concept of maximization of profits etc.). For this reason it may be rather difficult to really combine SNA and economic research. It is nearly impossible 
to present specific features of nodes in networks using only the tools available within the framework of the SNA.

The SNA approach has so far prevailed, although certain studies have also applied qualitative methods (certain forms of interviews). The most prominent among these studies were conducted by M. Maclean, C. Harvey and J. Press (2006) and M. Useem (1984). They have greatly contributed to the analysis of interlocking directorates, enriching the research with insider perspective and presenting stronger arguments for the general thesis that networks between companies also serve to fulfill individual interests. The interviews conducted as part of these studies provide a valuable addition to quantitative network analysis. The work by Maclean et al. (2006) is not limited to identifying the number of ties between 100 biggest companies in the UK and France, but it also includes an insider perspective on corporate elites, their assets, habitus and the purposes served by interlocking directorates. It must, however, be stressed that even though certain qualitative components are taken into account, the research still omits the features distinctive for two-tier systems.

The majority of the classical studies on interlocks have been conducted in countries with a one-tier governance system such as USA, the Netherlands and the UK. This might have led to a kind of a culture-blind approach in interlocking directorates studies. They frequently ignore the importance of cultural specifics, such as cultural patterns, informal institutions or national legislation as well as regulations of soft law. Although the studies on interlocking directorates concern an economic phenomenon, they rarely take into account cultural and institutional factors that characterize various types of capitalism. Such issues are mentioned only on the margins of research, for example when cultural differences are seen as an obstacle to the creation of transnational interlocks (Heemskerk et al., 2013).

As the studies carried out within one-tier systems have set up methodological and empirical standards for further analysis, certain scholars (for example Carroll, 2010; Heemskerk et al., 2013; Pawlak, 2010) have decided to treat executive and supervisory board as a single body (i.e. as a board of directors, without any actual distinctions). This was done mainly for the purpose of facilitating comparisons between the countries and networks of directors in each examined country. Such an approach, however, makes it more difficult to grasp a problem of ties occurring within capital groups and outside of them, and it makes it virtually impossible to identify the ties among executive boards members, which are more complex, have relatively informal character, and can be problematic from legal perspective as well as from the point of view of good practice.

Even though certain studies progressed from basic evaluation of the scale of interlocks to attempts at a more detailed description of their qualities, they still remained limited to a one-tier perspective. In the mid-1980s the distinction between the primary and secondary interlocks was introduced ${ }^{\text {iv }}$, which resulted in the observation of differences between the identified ties:

[secondary] interlocks that are induced between company $B$ and $C$ as a result of an interlock between $A$ and $B$ and $A$ and $C$ that is carried by an inside director of $A$ (Fennema and Heemskerk, 2016, p.10).

This concept of direct and indirect interlocks has emerged, (Mizruchi, 1992) with "direct" interlocks defined as firms that are directly linked through a common director and "indirect" interlocks as firms that each have a director on the board of a third, intermediary firm (see: Burris, 2005).

The main difference pertains to the problem of intentions underlying the decision to become involved in an interlock. As researchers have started to point out, some ties are formed intentionally while others are unintended (the cases where the connection is loose and appears accidental). The analysis of intentions was initially limited to decisions taken by 
organizations. For example, W. Carroll in his work from 2010 refers to the primary and secondary ties, thin and thick lines:

1. primary lines - interlocks created when an officer of one corporation sits on the board of another firm [...]

2. secondary lines - interlocks created when an outside director of one company serves as an outside director of a second company [...]

3. thin (single-director) lines

4. thick (multiple-director) lines (Carroll, 2010, p.22).

Carroll also attempts to create his own distinction based on the concept of social capital. He argues that the role of primary interlocks is to strengthen bonding social capital, while secondary ties are related to bridging capital. However, even these distinctions still fail to take into account the differences between corporate bodies in a two-tier system: a supervisory and an executive board. Carroll omits these differences even while referring in his studies to German corporations.

The analysis of German corporate governance system and interlocks occurring there conducted by T. Heinze (2004) provides a great exception, as the author actually distinguishes between executive and supervisory board's interlocks while presenting different patterns of networks (referring to them as directional and non-directional networks). Employing this distinction proved helpful in evaluating the trajectory of changes and erosion of interlocking directorates in Germany. The work by Heinze is among few studies that actually pay attention to institutional and structural consequences of two-tier governance system.

However, despite the exception of T. Heinze studies, a general conclusion can be ventured here that studies on interlocking directorates have not elaborated sufficiently on the well-grounded distinction of types of ties. This neglect, paired with cultural and institutional blindness might be the reason for the situation described by D. Palmer:

Little is known about the specific types of relationships that interlocking corporate directorates facilitate (Palmer, 1983).

The SNA perspective that dominates the studies on interlocking directorates is responsible for undue reduction of the complexity of this phenomenon, as it failed to develop tools that would enable their more detailed, deeper analysis, enabling us to see them in, so to speak, in greater resolution.

\section{Methodological case study}

The concept of mixed-methods approach is becoming increasingly popular in social sciences and it enables us to find answers to problems that could not have been solved if the methods applied had been limited to either quantitative or qualitative variety.

The goal of mixed methods research is not to replace either of these approaches but rather to draw from the strengths and minimize the weaknesses of both in single research studies and across studies. If you visualize a continuum with qualitative research anchored at one pole and quantitative research anchored at the other, mixed methods research covers the large set of points in the middle area. If one prefers to think categorically, mixed methods research sits in a new third chair, with qualitative research sitting on the left side and quantitative re-search sitting on the right side (Johnson \& Onwuegbuzie, 2004).

The approach is very pragmatic at its core, as it aims to obtain the most accurate picture of the examined issues and processes. This method is particularly valuable in adding "meaning" to regularities that have already been discovered (Johnson \& Onwuegbuzie, 2004, p. 21), which is exactly what has been missing from the studies on interlocking directorates.

In order to present how this approach can be employed in the studies on interlocks we will first refer to the observations and experiences from the studies conducted in the period 
from 2012 to 2014 as well as to the research carried out on a sample of 122 largest Polish companies. This research - which was fully presented in Szalacha-Jarmużek's work (2014) will serve here as a methodological instrumental case study.

The studies conducted between 2012 and 2014 aimed at providing answers to the question of the scope of interlocking directorates in Poland, the degree to which interlocks have developed, as well as the complexity of network of personal ties between biggest companies. In order to obtain the answers the first author set out to collect the data and evaluate quantitative aspects of interlocks in Poland. The author referred to the list of 500 most prominent corporations operating in Poland, published annually by a renowned newspaper Rzeczpospolita from which a sample of 122 companies was selected.

These 122 firms represented five key sectors of the Polish economy such as food processing and agriculture, banking, construction, energy, and pharmaceutical industries. The main hypothesis underlying the research claimed that the shape of networks created by directors would be derived from the structure of the given company and type of its ownership. The companies were divided into single bodies and those operating as capital/business groups. In respect of their ownership, the companies were categorized as divisions of foreign corporations, partially or totally state-owned firms and companies established and run by domestic owners (family business etc.).

Corporate governance system in Poland is two-tier, which means that according to the law companies are required to have an executive board and supervisory board. Once the data on the boards members were obtained from the National Court Register (Krajowy Rejestr Sądowy - KRS), a state body where all the information on every change within company's boards must be filed, it became obvious that separation between executive and supervisory board is a matter to be approached with full seriousness. Since the study concerned companies where executive and supervisory functions are vested in two separate bodies, the analyzed connections and networks were divided as follows:

- the ones formed by executive board members within (type 1) and outside capital groups (type 2)

- the ones formed by supervisory board members within (type 3) and outside capital groups (type 4).

The reason for separating two types of ties was that in a two-tier system legal restraints imposed on members of executive and supervisory boards differ greatly and these differences cannot be neglected. Executive board members are expected to take responsibility for everyday activities of the company and should devote their time and expertise to generating profits for the owners/shareholders, as well as exert a positive impact on stakeholders of the company. Executive officers/directors are supposed to increase effectiveness of the company and its assets, reduce environmental uncertainty and minimize internal conflicts. They can be seen as the driving power of the company. On the other hand, supervisory board members are supposed to bring balance and stability to their company. Their task is to protect the assets and the rights of shareholders. They are supposed to contribute their wisdom, expertise and a broader perspective for the benefit of the company. The control exercised by the supervisory board over the company in a two-tier system might be seen as a kind of a brake (when executive officers are playing "too hard, too risky") or a kind of an additional engine that encourages executive board to take a greater risk and boosts new activity.

To sum up briefly, 1433 links were identified, with 1.66 links per person and 5.83 links per company. However, the study demonstrated that only 60 of these 1433 ties were between the largest firms. The vast majority (1373) of the ties were created between big companies and much smaller firms that did not feature on the 500 List. As the study 
confirmed that the differences between the structure and type of company ownership correlated with the difference between the ties, the main hypothesis was verified positively.

In the sectors of economy where capital groups have more prominent presence (such as energy and construction) executive boards had higher mean of ties per person (7.02 and 7.77), while the mean number of ties in other sectors was lower: 4.86 in pharmaceutical industry, 5.42 food and agriculture and 6.42 banking. Both, supervisory and executive boards of firms with foreign capital had fewer interlocks, while companies with domestic capital had vast networks at both levels.

Looking at legal restrains and formal expectations present in a two-tier system, one might assume that executive officers (members of executive boards) would not have many ties at all, especially that they would avoid links with companies outside capital groups. However, the examination of 122 firms revealed that the ties formed by executive board members constituted a significant part of interlocking directorates. The study demonstrates that close attention to the differences between levels of management has helped to reveal more than just quantitative dimension of the examined phenomenon, extending to practices that go beyond the soft law. And this has led to a particularly valuable finding that multiple ties exist outside of capital groups, with the mean number of 2.71 ties outside capital groups per company:

Table 1. The differences in the number of ties in Polish corporate governance system

\begin{tabular}{lcc}
\hline & $\begin{array}{c}\text { Mean number of ties within capital } \\
\text { groups [per company] }\end{array}$ & $\begin{array}{c}\text { Mean number of ties outside } \\
\text { capital groups [per company] }\end{array}$ \\
\hline Executive board members & 3.16 & 2.71 \\
\hline Supervisory board members & 1.42 & 4.30 \\
\hline
\end{tabular}

Data source: own research conducted in a period 2012-2014 for 122 biggest firms in Poland

Taking into account the specifics of a two-tier system has helped to discover that executive managers relatively frequently have personal ties with companies that have nothing in common with large corporations employing them. What is even more interesting, within a number of 582 ties created outside capital groups, there is a mean of 0.96 tie per company for relations between executive boards' members and executive boards from the outside firms. The nature of these ties, even the informal ones, looks rather vague, and one of the main research questions that so far have not been addressed is whether these ties create an informal institution, as defined by G. Helmke and S. Levitsky (2004). To give just one example, it remains unknown why higher level managers maintain such connections and how these links are perceived by the members of their company's boards. In the in-depth interviews that followed the network analysis, the insiders raised issues concerning loyalty of directors sitting on several boards, the amount of time they could devote to one company, as well as their ability to process great amount of information. The interlocutors expressed their doubts concerning the ability of those holding more than two positions at the time to run or control a large company (Szalacha-Jarmużek, 2014). Even more importantly, the majority of the interviewees were surprised by the results of the research concerning executive boards' members. They expressed puzzlement at the finding that executive officers were engaged in a number of various firms, while good practices recommend exactly the opposite, i.e. focusing solely on best interest of a single company/business group.

Had the distinction between the supervisory and executive boards been omitted in the study, it would not have yielded such interesting results, which proves the importance of factors related to distinctive types of corporate governance. Therefore, greater attention paid to these distinguishing factors may lead to a better understanding of actual dynamics of the processes governing the creation of networks. 
The research conducted in Poland demonstrated that to study - from sociological perspective - informal aspects and informal institutions related to interlocking directorates a different methodological approach should be adopted. Even within a one-tier system the distinction between the ties formed by executive and non-executive directors would reveal valuable patterns of behavior. Therefore, new research on interlocking directorates definitely should:

1. make distinctions between ties within capital groups and outside them

2. make distinction between relations of executive boards members from those of supervisory boards (in case of a one-tier system between executive and non-executive officers)

3. take legal constrains and types of ownership into consideration

4. combine quantitative and qualitative analysis.

Most studies have been limited to quantitative analysis (network analysis based on judicial records or other official documents) and they lack a qualitative component. It may be stated that such an approach has hampered the research, confining it to analyses that from the sociological point of view are relatively superficial and has made it impossible to gain deeper insights that could provide satisfactory questions pertaining to the causes behind personal ties between companies.

\section{Discussion: Possible solutions}

If studies on interlocking directorates are to progress towards providing explanations rather than merely identifying interlocks, and especially if they are to yield insights that could have practical consequences for managers, a mixed-method approach might prove a way to achieve such goals. Basing on experience from the study conducted in Poland, where network analysis was supported by IDIs, we recommend to develop a framework of research encompassing eight steps, grounded in the mixed method. The study should not only describe the shape of a network, but it should also provide detailed answers to such essential questions as:

- What factors prevail in creation of ties on a level of executive board and on a level of supervisory board?

- What kinds of motivations prevail in forming ties outside capital group on a level of executive board?

- What advantages/risks are most common for interlocks with outside companies?

- Are interlocks an informal institution? Are there any positive or negative sanctions related to formation of interlocking directorates?

- Are there differences in how ties are perceived on executive and on supervisory level by corporate elites?

- Can any of the observed network models of interlocking directorates be described in terms of sustainability?

- Are we observed network effects (eg. diffusion of interlocking directorates model from one company to another)? Or maybe we are dealing with spontaneous replication of a network pattern (resulting from similar structural factors)?

These last two issues are discussed in contemporary economics in a different context (see Lechman, 2018). But it would be a good starting point for combining the economic perspective and the sociological perspective.

Following J.W. Creswell's work and concept of timing in the mixed method (2009), it is convenient to gather quantitative and qualitative data sequentially. Recalling experience from our study, it is better to gather quantitative data first, as then it can provide a background 
and guidance for preparation of the IDIs. Other issues such as weighting, mixing and theorizing as Creswell writes, should be resolved in our opinion in a priority should be given to quantitative data (weighting), the rest of data are embedded (mixing), and theorizing is rather implicit in such case (Creswell, 2009, pp. 206-207). Onwuegbuzie and Teddlie's (2003) seven-stage framework of the mixed method data analysis consists of the following steps: reduction, display, transformation, correlation, consolidation, comparison and integration. These stages can easily be adapted to the studies on interlocking directorates. In the following parts of the paper a proposal of nine stage research of interlocking directorates is presented (the acronym QUAN stands for quantitative and QUAL refers to qualitative analysis). The proposal follows both the concept of mixed-method and experience gathered during studies conducted in Poland.

The research on interlocking directorates always takes place in a specific economy/country. Therefore step 1 of research plan involves desk research on legal aspects of interlocks in a specific corporate governance system, as each corporate system carries distinctive features and operates in a different environment, with various legal restrictions and good practices (or other forms of soft law) in place. Such research is necessary to set the record straight in respect of formal limitations for individual activities. Desk research should also involve a description of the institutional framework of capitalism, together with dominant formal institutions and cultural patterns that represent important features of a given economic system. Then, the study encompasses an analysis of the types of ownership characterizing each of the examined companies, i.e. it should be specified whether a given firm is a division of a foreign corporation, is partially or totally state-owned, or is a company established and run by domestic owners (family business etc.).

In step 2 SNA is employed, on the basis of judicial records. A map of ties of corporate boards for a given number (preferably 100 or 200) of the biggest companies in the country of interest must be created. Such a map should clearly distinguish between ties formed by the members of executive boards (or executive officers), the ones sitting on supervisory board (or non-executive officers), as well as those within capital groups and outside of them. Networks should be described with reference to traditional SNA features such as density, centrality of nodes, etc.

In step 3 individual in-depth interviews are run following a standard list of questions/topics. We propose to select a sample of firms with specific networks ${ }^{\mathrm{v}}$ and contact them in order to run several in-depth interviews with the members of their boards - this step may be particularly difficult as the permission is usually not easily granted (see: Shenton \& Hayter, 2004). The interviews can also help to describe the level of institutionalization of interlocking directorates (i.e. negative and positive sanctions, measures of formality, etc.). IDIs will complement the current state of knowledge about interlocks (obtained in step 1) with new information and observations concerning the motivations and the goals achieved through interlocking directorates as well as the attitudes towards this phenomenon (from the perspective of an organization and individual, treated separately). Further, the research can progress to a new set of IDIs in order to gain comprehensive knowledge concerning transactional costs related to interlocking directorates as well as the threats and benefits related to them. IDIs run with a new set of board members (including higher management of the largest companies operating in a given country) may lead to interesting findings. It should be stressed at this point that the proper selection of interviewees is of utmost importance (Harvey, 2011). They must be knowledgeable and preferably have a lot of professional experience, rendering their opinions truly valuable and fit for our purposes (see: Abermach \& Rockman, 2002).

Steps 4 and 5 refer to the presentation of data. In this case results from QUAN and QUAL research are presented in simplified forms. Obviously QUAN are presented in forms 
of graphs (chosen software like UCINET or other will supply necessary tools for that). A color code should be used in graphs to represent types of links while other graphic tools should be employed to present information about the types of ownership. Below we present an example of a graph with color-coded links. Each nod represents a member of board of a given company. The links formed by executive boards members are orange and the ones formed by supervisory directors are blue). Dotted lines represent links outside capital group. The figure presents networks for 10 largest construction companies in Poland and it shows that most companies have links with companies from other sectors of economy. There is only one example of a tie between two construction firms (Budimex \& Mostostal Warszawa).

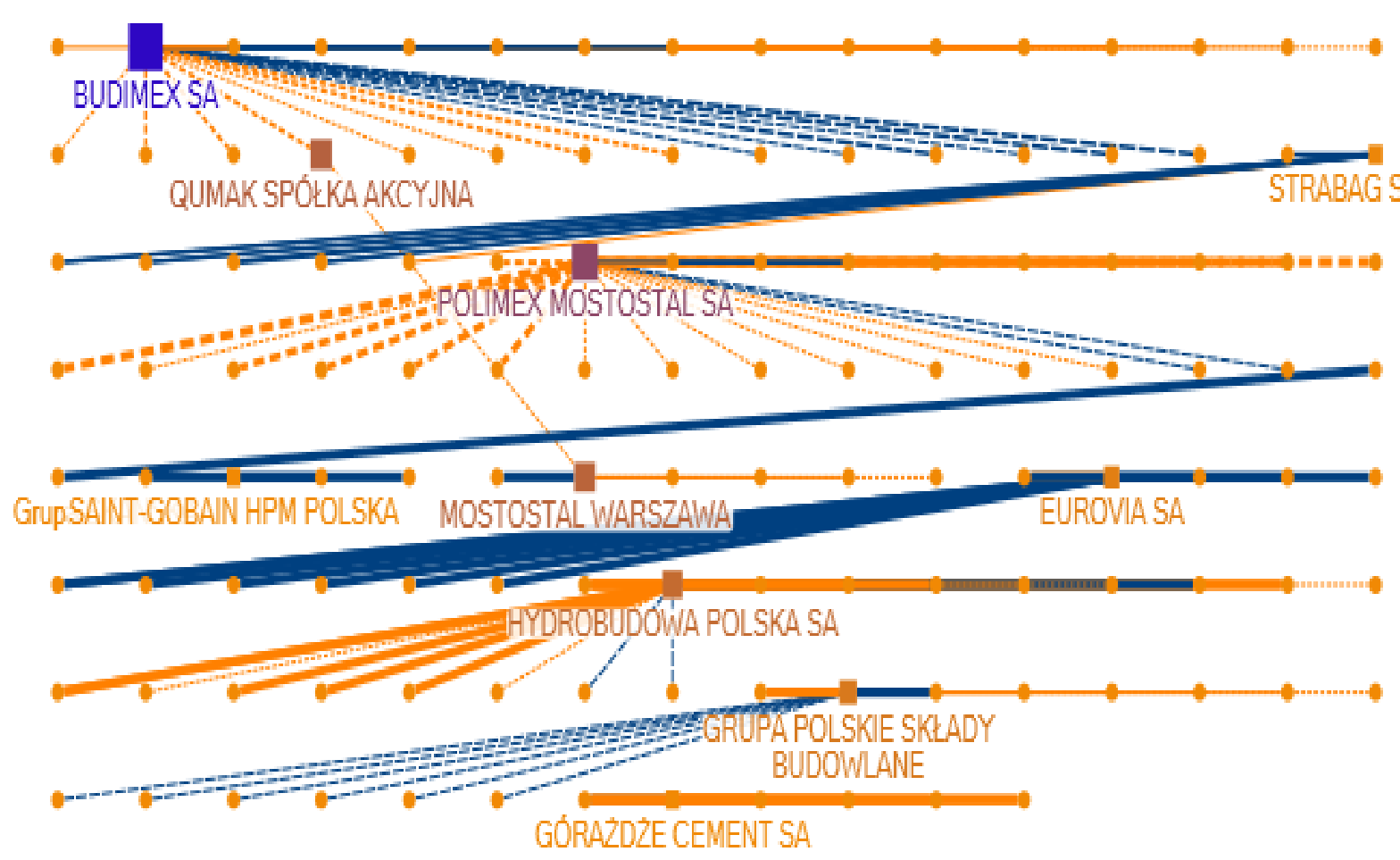

Figure 1. The network of 9 biggest construction companies in Poland

Data source: own research conducted in a period 2012-2014 for 122 biggest firms in Poland

Preferably, the QUAL results should be presented in the form of a cloud of tags. From IDIs the most present notions in interviews, the terms frequently used in description of attitudes towards interlocking directorates or the ones used to describe opinions and motivations will appear in a cloud (the importance of each tag will be rendered by the use font size or colour). These two steps will enable us to obtain a simplified picture of the ties and insiders' opinions about them.

Steps 6 and 7 refer to data transformation. The aim of this step is to give additional, sociological meaning to QUAN data. So we recommend to regroup identified links into two possible types - bonding-formal and bridging-informal ones. The issue of formality is linked directly to presence of capital groups - links within capital groups are formal (as they are created by boards in order to sustain/create better control). The ties created by executive and supervisory boards' members should be divided into bridging and bonding ones (referring to the idea presented by W. Carroll (2010) and concepts of social capital by R. Putnam (2001), M. Woolcock (2001), and J. Coleman (1988)). A matrix of ties will look like this: 
Table 2. Types of links in two-tier corporate governance system

\begin{tabular}{lll}
\hline & Executive board member's link & $\begin{array}{l}\text { Supervisory board member's } \\
\text { link }\end{array}$ \\
\hline Within capital group & Bonding, formal & Bonding, formal \\
\hline Outside capital group & Bridging, informal & Bridging, informal \\
\hline
\end{tabular}

Authors' typology based on literature and own research conducted in a period 2012-2014 for 122 biggest firms in Poland.

Afterwards, we can count how many ties are bonding and formal and how many of them are bridging and informal - the graph will be transformed into numbers (preferably expressed as percentages). In the case of QUAL data, we suggest that the frequency of the selected tags should be also presented as a percentage - an idea is to count the frequency with which the given notion appears in IDIs and to transform this information into percentage for all the repeatable terms.

Step 8 involves data correlation. The aim here is to arrange and confront the data obtained in QUAN and QUAL parts of the research in order check for any regularities. It is important to verify if the most common opinions/notions are correlated with the most frequent types of links. One example may be the situation where the majority of the insiders express extreme caution towards personal links and at the same time there are few bridging links in a network.

Step 9 - data consolidation and the final stage of research is devoted to an overall presentation of the shape of interlocking directorates in a given country, together with the proposed thesis concerning social factors responsible for the discovered networks.

The proposed methodological approach towards interlocking directorates encompasses an idea that the discovered shape of the network constitutes an independent variable that might be influenced by several factors which should be discovered in the following steps: (1) an analysis of social network taking into consideration the division between supervisory and executive boards as well as differences between the ties existing within capital groups and outside of them [the quantity and types of connections as dependable variables], (2) an analysis of legal conditions and restrictions that have impact on ties between firms [legal aspects as a dependable variable], (3) an analysis of personal attitudes and individual willingness to become involved in interlocking directorates [attitudes as dependable variable], (4) an analysis of capital structure (ownership) of companies involved in networks [the size of the company, foreign or domestic capital and its capital structure as a dependable variable]. With this approach more details about factors that influence interlocks and big firms can be revealed.

Making interlocking directorates more "transparent" in sociological terms is important also from the perspective of management issues. As was mentioned earlier, boards' members are agents of an owner-principal in a company, their every action that takes place outside the firm has an impact on their performance as agents. Therefore a closer attention to issues such as motivations to engage in interlocks, factors that lead to the formation of personal ties between companies is crucial for individuals and organizations interested in the success of a large company. These issues must be presented in a way that will be clear and understandable for owners and managers of big corporations. Interviews run with board's members in Poland (Szalacha-Jarmużek, 2014) have shown, that insiders often do not pay much attention to interlocking directorates. As a consequence, their companies are managing this topic on a very small scale. Therefore new operationalization is much needed in order to form some practical implication for managers and boards for the future. 


\section{Conclusions}

Two-tier corporate governance systems with their legal institutions create two different structures within which interlocking directorates occur. The executive and supervisory boards' members face different expectations and legal limitations in their professional pursuits- in certain cases, to take Poland as an example, these distinctions are evident and they constitute important factors that shape interlocking directorates. Nevertheless, the majority of research conducted over the last 50 years has failed to take these factors into account. At the same time, (as was mentioned earlier) many scholars have frequently observed that the outcomes of studies on this phenomenon are not entirely satisfactory for social scientists. What they found lacking were answers to questions concerning motives, interests, as well as certain social consequences of interlocking directorates. There are two prevailing strategies that are responsible for this state of research.

Firstly, most of the researchers seem to concentrate on basic quantitative aspects of the identified networks, such as the number of ties, the density of the network, and the centrality of nods. They assume that the ties created by different directors can be treated as if they were "equal" and had the same social value. Yet, it seems that even in the studies concerning a onetier system the distinctions between primary and secondary lines, thick and thin lines (ties) are not examined in sufficient detail. This is due to the fact that the studies fail to analyze these distinctions in relation to social factors underlying the decisions and motivations of those holding specific positions on corporate board. The omission by many scholars of the obvious fact of the existence of different governance structures in two-tier systems seems to be a consequence of this neglect.

Secondly, we would like to point to the absence of qualitative research that would directly follow the outcomes of SNA. A well-designed set of IDIs (with well-chosen subjects as opposed to ones selected in a random or accidental manner) should be aimed at identifying inducements, incentives, and informal sanctions. Only such an approach can ensure that the research will meet the objectives of sociological studies, allowing us to progress beyond merely correlational analysis and arrive at causal explanations. To conclude, it seems that a great number of studies on elites are grounded in a pre-conceived idea that there must be "more" behind the activities of the members of the elite, that the pursuit of their goals and interests is supported by specific organizational forms and driven by sophisticated processes. Prominent presence of corporations in the Western world renders the topic of business elites both fascinating and socially important. Nevertheless, as has been argued in this paper, our knowledge of networks of corporate elites that have been identified and analyzed in a great number of countries remains incomplete, as we still lack significant explanations.

The proposal presented in this paper is grounded in the research conducted in Poland, yet it should be tested further in a new study. The mixed-method approach and the choice of the two-tier system as the subject of research seems to provide the true "remedy" for the weakness pointed out by Mizruchi (see: Fennema \& Heemskerk, 2016), Peng et al. (2000) and others who appreciate the need for a deeper insight into interlocking directorates. A close and detailed observation of networks created by executive and supervisory boards members, followed up by a set of interviews, seems to be the best way to obtain more satisfactory answers and arrive at a fuller sociological picture of the key actors and their social impact on business. Therefore, a choice of a two-tier system as a subject of research carries double benefits: firstly, it brings new knowledge and new data into the body of research on interlocking directorates and secondly, it increases sensitivity to social factors that lie behind a decision to create a tie between companies. 


\section{Acknowledgments}

The research leading to these results has received funding from the project titled " Interlocking directorates" w Polsce - socjologiczna próba zdiagnozowania fenomenu" in the frame of the Ministry of Science and Higher Education program, research grant agreement number 3432/B/H03/2010/38.

\section{References}

Aberbach, J. F., \& Rockman, B. A. (2002). Conducting and coding elite interviews. Political Science and Politics, 35, 673-676.

Barabási, A.-L., \& Albert, R. (1999). Emergence of scaling in random networks. Science, 286 (5439), 509-512.

Bellenzier, L., \& Grassi, R. (2013). Interlocking directorates in Italy: persistent links in network dynamics. http://link.springer.com/article/10.1007/s11403-013-0119-8 (access 4.04.2017).

Buch-Hansen, H. (2014). Interlocking directorates and collusion: An empirical analysis. International Sociology, 4(29), 249-267.

Bunting, D., \& Barbour, J. (1971). Interlocking Directorates in Large American Corporations, 1896-1964. The Business History Review, 45(3), 317-335.

Burris, V. (2005). Interlocking Directorates and Political Cohesion among Corporate Elites. American Journal of Sociology, 111(1), 249-283.

Carretta, A., Farina, V., Gon, A., \& Parisi, A. (2012). Politicians 'on Board': Do Political Connections Affect Banking Activities in Italy?. European Management Review, 9, 7583.

Carroll, W. (2010). The Making of a Transnational Capitalist Class: Corporate Power in the $21^{\text {st }}$ century. London - New York: Zed Books.

Coleman, J. (1988). Social Capital in the Creation of Human Capital. American Journal of Sociology, 94 Supplement, 95-120.

Creswell, J. W. (2009). Research Design. Qualitative, Quantitative and Mixed-Methods Approaches. London: Sage Publications.

Degenne, A., \& Forse, M (1999). Introducing social networks. Trans. by A. Borges. London: Sage Publications.

Di Donato, F., \& Tiscini, R. (2009). Cross ownership and interlocking directorates between banks and listed firms: an empirical analysis of the effects on debt leverage and cost of the debt in the Italian case. Corporate Ownership \& Control, 6(3), 473-481.

DiMaggio, P. (1998). The New Institutionalism: Avenues of Collaboration. Journal of Institutional and Theoretical Economics, 154 (4), 696-705.

Fennema, M. (1982). International networks of banks and industry. Dordrecht: Springer.

Fennema, M., \& Heemskerk, E. (2016). When Theory meets Methods: The Naissance of the Field of Corporate Interlock Research". SSRN, https://ssrn.com/abstract=2827627 (access 4.04.2017).

Fich, E. M., \& White, L. J. (2005). Why do CEOs reciprocally sit on each other's boards?. Journal of Corporate Finance, 11, 175-195.

Flyvbjerg, B. (2001). Making Social Science Matter: Why Social Inquiry Fails and How It Can Succeed Again. Cambridge University Press

Giddens, A. (1984). The Constitution of Society. Outline of the Theory of Structuration. Berkeley: University of California Press.

Granovetter, M. S. (1973). The Strength of Weak Ties. American Journal of Sociology, 78(6), 1360-1380. 
Hałas, E. (2010). Towards the World Culture Society. Florian Znaniecki's Culturalism. Frankfurt am Main: Peter Lang.

Hashim, H. A., \& Rahman, M. (2011). Multiple Board Appointments: Are Directors Effective?. International Journal of Business and Social Science, 17(2), 137-143

Harvey, W. S. (2011). Strategies for conducting elite interviews. Qualitative Research, 11, 431-441.

Heemskerk, E. M., \& Schnyder, G. (2008). Small states, international pressures, and interlocking directorates: the cases of Switzerland and the Netherlands. European Management Review, 5(1), 41-54.

Heemskerk, E. M., Daolio, F., \& Tomassini, M. (2013). The Community Structure of the European Network of Interlocking Directorates 2005-2010. PLoS ONE, 8(7), e68581.

Heinze, T. (2004). Dynamics in the German system of corporate governance? Empirical findings regarding interlocking directorates. Economy and Society, 33(2), 218-238.

Helmke, G., \& Levitsky, S. (2006). Introduction. In: G. Helmke, S. Levitsky (eds.). Informal Institutions and Democracy. Lessons from Latin America. Baltimore: John Hopkins University Press, pp. 1-32.

Johnson, B., \& Onwuegbuzie, A. J. (2004). Mixed Methods Research: A Research Paradigm Whose Time Has Come. Educational Researcher, 33(7), 14-26.

Kadushin, C. (1995). Friendship among the French Financial Elite. American Sociological Review, 60, 202-221.

Lechman, E. (2018). Networks Externalities as Social Phenomenon in the Process ICT Diffusion. Economics and Sociology, 11(1), 22-43, doi:10.14254/2071-789X.2018/11$1 / 2$

Maclean, M., Harvey, C., \& Press, J. (2006). Business elites and corporate governance in France and the UK. London: Palgrave.

Mintz, B., \& Schwartz, M. (1981). Interlocking directorates and Interest group Formation. American Sociological Review, 46, 851-896.

Mizruchi, M. S. (1992). The structure of corporate political action. Cambridge: Harvard University Press.

Ong, C-H., Wan, D., \& Ong, K-S. (2003). An exploratory study on interlocking directorates in listed firms in Singapore, Corporate Governance: An International Review, 11, 322334.

Onwuegbuzie, A. J., \& Teddlie, C. (2003). A framework for analyzing data in mixed methods research. In: A. Tashakkori, C. Teddlie (eds.), Handbook of mixed methods in social and behavioral research. Thousand Oaks, CA: Sage, pp. 351-383.

Palmer, D. (1983). Broken Ties: Interlocking Directorates and Intercorporate Coordination. Administrative Science Quarterly, 28(1), 40-55.

Parker, W. D. (2006). Methodological Individualism vs. Methodological Holism: Neoclassicism, Institutionalism and Socionomic Theory. http://www.socionomics.org/pdf/neoclassicism_institutionalism.pdf_ (access: 11.12.2017).

Pawlak, M. (2010). Wielokrotne mandaty jako narzędzie zarządzania w grupach kapitałowych. In: M. Pawlak (ed.), Nowe tendencje w zarzadzaniu. Lublin: KUL, pp. 29-40.

Peng, M., Kecin, A., \& Wang, D. (2001). Interlocking Directorates as Corporate Governance in Third World Multinationals: Theory and Evidence from Thailand. Asia Pacific Journal of Management, 18, 161-181.

Pombo, C., \& Gutiérrez, C. L. (2011). Outside directors, board interlocks and firm performance: Empirical evidence from Colombian business groups. Journal of Economics and Business, 63 (4), 251-277 
Putnam, R. D. (2001). Social Capital: Measurement and Consequences. Isuma: Canadian Journal of Policy Research, 2, 41-51.

Ribeiro, F., Colauto, R. D., \& Clemente, A. (2016). Determinants of Board Interlocking in the Brazilian Capital Market, Revista de Educação e Pesquisa em Contabilidade, 10(4), 389-405.

Rommens, A., Cuyvers, L., \& Deloof, M. (2007). Interlocking Directorates and Business Groups: Belgian Evidence. Retrieved 4.04.2017 from http://www.fma.org/Prague/Papers/RommensInterlocksFMA.pdf.

Santos, R., Silveira, A., \& Barros, L. (2012). Board interlocking in Brazil: Directors' participation in multiple companies and its effect on firm value and profitability. Latin American Business Review, 13, 1-28.

Schoorman, F. D., Bazerman, M. H., \& Atkin, R. S. (1981). Interlocking directorates: a strategy for reducing environmental uncertainty. Academy of Management Review, 6, 243-251.

Scott, J. (1991). Networks of corporate power: A comparative assessment. Annual Review of Sociology, 17, 181-203.

Shenton, A., \& Hayter, S. (2004). Strategies for gaining access to organizations and informants in qualitative studies. Education for Information, 22, 223-231.

Sicilia, C., Sallan, H., \& Simo, P. (2016). The Spanish corporate structure through interlocking directorates. Cuadernos de Gestion, 16(1), 63-84

Stake, R. E. (1994). Case studies. In: N.K. Denzin and Y.S. Lincoln (eds.), Handbook of qualitative research. Thousand Oaks, CA: Sage, pp. 236-247.

Stening, B., \& Wan, T. 1984. Interlocking directorates among Australia's largest 250 corporations. Australia and New Zealand Journal of Sociology, 20, 47-55.

Szalacha-Jarmużek., J. (2014). Między zaufaniem a elitarnościa. Krzyżujace się zarządy $i$ rady nadzorcze $w$ Polsce - socjologiczna analiza zjawiska. Torun, Wyd. WSB

Useem, M. (1984). The Inner Circle. New York: Oxford University Press.

Woolcock, M. M. (2001). The place of social capital in understanding social and economic outcomes. Isuma: Canadian Journal of Policy Research, 2 (1), 11-17.

van der Pijl, K., Holman, O.H., \& Raviv, O. (2011). The resurgence of German capital in Europe: EU integration and the restructuring of Atlantic networks of interlocking directorates after 1991. Review of International Political Economy, 18(3), 384-40.

Van Ees H., \& Postma, T.J. (2004) Dutch Boards and Governance A Comparative Institutional Analysis of Board Roles and Member (S)election Procedures. International Studies of Management \& Organization, 34(2), 90-112.

van Veen, K. \& Kratzer, J. (2011) National and international interlocking directorates within Europe: Corporate networks within and among fifteen European countries. Economy and Society, 40(1), 1-25.

\footnotetext{
i It seems that the majority of studies fail to provide insights into the phenomenon of "preferential attachment" within networks, the aspect which is rather important for network analysis (Barabasi and Albert, 1999; Heemskerk et al., 2013).

${ }^{\text {ii }}$ From a philosophical point of view no research in the social sciences can ever establish causality (see: Flyvbjerg, 2001), but in authors' perspective it is about a cause-effect relationship that results in an explanation.

iii In other cases (Bellenzier and Grassi, 2013) networks analysis took the form of "temporal networks", i.e. the ties between companies were analyzed from a historical perspective over a selected time span. Such research was focused on methods that helped to describe the quantitative parameters of the examined phenomenon.

iv Obviously, the classical distinction between strong and weak ties by M. Granovetter (1973) preceded any further attempts to differentiate ties within networks.

${ }^{\mathrm{v}}$ For example very vast or extremely connected on a board level.
} 